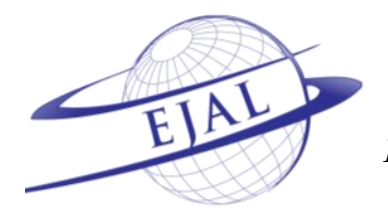

\title{
Foreign Language Anxiety and Enjoyment in an Imagined Community
}

\author{
Majid Elahi Shirvan a * (D), Nahid Talebzadeh a † (D) \\ a University of Bojnord, University of Bojnord Campus, Bojnord, Iran
}

Received 21 October 2017 | Received in revised form 3 March 2018 | Accepted 24 July 2018

\section{APA Citation:}

Shirvan, M. E., \& Talebzadeh, N. (2018). Foreign language anxiety and enjoyment in an imagined community. Eurasian Journal of Applied Linguistics, 4(2), 109-133. doi: 10.32601/ejal.464043

\begin{abstract}
Learning a foreign language can be frustrating for some people and very enjoyable for some others. Emotions are one of the most important factors in the use of English as a foreign language located in the center of attention of many researchers. One of the emotion-inducing contexts for learning English as a foreign language can be the setting of an imagined community. Our focus in this study was on the emergence of emotions, both positive and negative, of three groups of six university students engaged in an English-speaking literature criticism TV program as an imagined community. The program encompassed a specific day to discuss a fiction and a final report of the program specified for publication in one of the well-established literary bulletins. Each member constructed a specific imagined identity in each group as critics, photographers, reporters, and presenters competing with each other for the final selection of the best critique and presentation on the discussion day as well as the publication of the best report. A triangulation of data was gathered including an interview, observation, an open-ended questionnaire as well as personal journals which were qualitatively analyzed. The results showed the emergence of enjoyment resulting from the constructed imagined identities in the classroom as well as facilitative negative emotions such as anxiety leading to the consolidation of the participants' imagined affiliations.
\end{abstract}

(C) 2018 EJAL \& the Authors. Published by Eurasian Journal of Applied Linguistics (EJAL). This is an open-access article distributed under the terms and conditions of the Creative Commons Attribution license (CC BY-NC-ND) (http://creativecommons.org/licenses/by-nc-nd/4.0/).

Keywords: Anxiety; enjoyment; imagined community; negative emotions; positive emotions

\section{Introduction}

Imagined community (Norton, 2000, 2001), referring to individuals' imagined affiliations with certain groups, is a desired community that provides the opportunity to imagine different identity options in the future possibilities for an enhanced range of identity options in the future (Norton\& Toohey, 2011). What language learners imagine in an imagined community offers them the possibility to think about the person they desire to become and take advantage of it in their language learning and development (Schwieter, 2013). By imagination, Wenger

\footnotetext{
* Corresponding author.

E-mail address: elahimajid64@gmail.com ; m.elahi@ub.ac.ir

† nahidtalebzadeh@yahoo.com
} 
(1998) means transcending time and space by viewing oneself with new images in a new world as well as considering the associations among these images. What individuals imagine as a future possibility can lead to higher motivation in learning the language (Norton, 2000) as well as a strong sense of joy and fulfillment when reaching their goal.

In a second language acquisition (SLA) context, emotion has not much been taken into account (Deweale, 2015). Recent studies on emotion show that negative emotions such as anxiety have received more attention compared to positive emotions (see Dewaele, Witney, Saito, \& Dewaele, 2017; Horwitz, 2001; Lu \& Liu, 2011; MacIntyre, 1999; Saito, Garza, \& Horwitz, 1999; Scovel, 1978) and; thus, positive emotions require further research (Dewaele et al., 2017). Murphey (2010) acknowledged the importance of emotions in SLA explaining that even though SLA classrooms are places where emotions are overriding, they were largely unnoticed. Although anxiety has been described as a disruptive function in learning (Arnold \& Brown, 1999), one must keep in mind that negative emotions are not always malfunctioning (Gregersen \& MacIntyre, 2014) since some of them like anxiety is "multi-faceted" (Horwitz, 2010, p.145). Even though facilitative anxiety might not be farfetched (Hewitt \& Stephenson, 2012; Kleinmann, 1977), the question Horwitz asks is whether they actually exist (1990) or they might refer to another construct like enjoyment (Deweale \& MacIntyre, 2014). Considering this concern, Deweale \& MacIntyre (2016) asserted that negative and positive emotions together represent the right and left feet of learners meaning that they are two separate dimensions or as they previously maintained, they are like the two faces of Janice (Deweale \& MacIntyre, 2014). Recent studies on emotions in SLA have regarded both emotions and their representations like foreign language classroom anxiety (FLCA) and foreign language enjoyment (FLE) (e.g. Dewaele \& MacIntyre, 2014, 2016; Dewaele, MacIntyre, Boudreau, \& Dewaele, 2016; Deweale, \& Deweale, 2017).

Deweale and MacIntyre (2014) developed an FLE scale indicating positive emotions towards learning, peers as well as the teacher and found a partial relation between positive and negative emotions indicating that they are separate dimensions. Based on the same dataset, Deweale and MacIntyre (2016) investigated gender differences in experiencing positive emotions. They found that females experienced more enjoyment compared to males. Elahi Shirvan and Taherian (2018), using latent growth curve modeling, investigated the changes in enjoyment and anxiety in language learners and confirmed that, despite the strong association between the two variables, they exist as two different constructs.

Furthermore, the fluctuations of positive and negative emotions via an idiodynamic method (MacIntyre \& Legatto, 2011) in anxiety (Elahi Shirvan \& Talebzadeh, 2017), in enjoyment (Elahi Shirvan \& Talebzadeh, 2018 a), and in both variables (Boudreau, MacIntyre, \& Deweale, 2018) have been recently explored. Very recently, Deweale and Alfawzan (2018) investigated both enjoyment and anxiety in foreign language performance and found that enjoyment weighs more in learners' performance than anxiety. Also, investigating the emotions of students 
majoring in English in their use of English language as a foreign language, Piniel and Albert (2018) reported that the most frequently experienced emotions by these learners were anxiety and enjoyment and the emergence of these emotions depend on the context of language use. In this study, we postulate that one of these contexts can be imagined community since the imagined affiliations constructed by foreign language learners via transcending time and pace seem emotion invoking. Thus, the main purpose of this study was to create an imagined community for a group of students and to explore the emergence of their positive and negative emotions including anxiety and enjoyment while they were actively involved in the constructed imagined community.

\section{Literature review}

The following literature review encompasses definitions, theoretical frameworks, and practical studies on the concepts of imagined community and emotions. It also covers the association between emotions and imagined community. Finally, it deals with the need for the investigation of emotions within the structure of imagined community.

\subsection{Emotions}

Emotions are the "heart of the foreign language learning process" because without them inadequacy in learning would take place (Deweale, 2015, p 3.). According to Reeve (2015), emotions are "short-lived, feeling-purposive-expressive-bodily responses" (p. 340) which contribute to one's adaptation to many different events. One of these events can be related to thinking about the person whom learners desire to become in which they might experience a gamut of all feelings from anxiety to enjoyment. Imagined community provides learners with different imaginary events or occasions in which learners are supposed to make the required adaptations and as asserted by Reeve (2015), these adaptations are accompanied with emotional responses. Therefore, the importance of the role of emotions in language learning events should be considered in research on language learning (MacIntyre \&Vincze, 2017). Before explaining the need for the exploration of emotions within the air of imagined communities, taking a look at the review of major definitions and findings of the two realms seems necessary.

One well-investigated negative emotion in the process of learning and using a foreign language is anxiety. MacIntyre (1999) defined foreign language anxiety as the negative reaction while using a second language. Anxiety has been investigated in many areas of language learning such as listening (e.g. Elkhafifi, 2005; Rivers, 1981), reading (e.g. Saito et al., 1999), writing (e.g. Cheng, 2002; Cheng, Horwitz, \& Shallert, 1999) with the Foreign Language Classroom Anxiety Scale (FLCAS) (Horwitz, Horwitz, \& Cope, 1986) being the most frequently used measure of anxiety (see Horwitz, 2010). Recently, states of anxiety have been investigated from an idiodynamic perspective (e.g. Boudreau, et al., 2018; Elahi Shirvan \& Talebzadeh, 
2017, Gregersen, MacIntyre, \& Meza, 2014) showing that anxiety is dynamic in its nature and many variables might affect it causing moment-to-moment changes in the learners' anxiety. These variables can be events like giving a class presentation (Gregersen, et al., 2014), familiarity with the interlocutors (Elahi Shirvan \& Talebzadeh, 2017), willingness to communicate about different topics (MacIntyre \& Legatto, 2011) as well as oral tasks and foreign language communication (Boudreau, et al., 2018). The imagined affiliations learners make with regard to certain groups in an imagined community might involve many of these influencing factors; thus, rendering learners go through vibes of anxiety.

On the other hand, exploring positive emotions, expected to be seriously studied in the field of applied linguistics (Bown \& White, 2010; Imai, 2010), have recently drawn the attention of researchers (e.g. Boudreau, MacIntyre, \& Dewaele, 2018; Elahi Shirvan \& Talebzadeh, 2018a; Elahi Shirvan \& Taherian, 2018; Elahi Shirvan \& Talebzadeh, 2018b, Dewaele \& MacIntyre, 2014; Dewaele et al., 2016; Dewaele \& Pavlenko 2001; Dewaele et al., 2017). Dewaele and Pavlenko (2001) were the pioneers to develop the first big online questionnaire asking participants to express their feelings of love, anger, and swearing towards different interlocutors with more than 1500 adult multilinguals. Recent works on emotion have grasped other researchers' attention to this area (e.g. Garrett \& Young, 2009; Gregersen, et al., 2014; Swain, 2013). Both positive and negative emotions must be observed simultaneously since they are like the right and left feet of the learners in the learning process (Dewaele et al., 2016).

Fredrickson (2003) made a clear distinction between positive and negative emotions explaining that positive emotions such as joy, interest, contentment, pride, and love indicate peoples' ability to "broaden their momentary thought-action repertoires" (p. 219). Language teachers need to provide an environment in which the students feel emotionally safe and encouraged to experiment (see Arnold, 1999; Baider, Cislaru, \& Coffey, 2015; Borg, 2006; Dewaele, 2015; Dörnyei \& Csizer, 1998; Dörnyei \& Murphy, 2003; Gregersen \& MacIntyre, 2014; Williams, Burden, Poulet, $\&$ Maun, 2004). One of these experiments can be related to the opportunities given to students to think about, or imagine the desirable person they like to become. This might place them in an emotional zone of joy, pride, and love.

Gender differences in the emergence of enjoyment within the context of imagined communities can be also addressed. Dewaele et al. (2016) studied gender differences in emotional experiences showing that females experience enjoyment more than males. But alongside gender differences, they also observed different positive and negative emotions including pride, joy, interest, love, nervousness, and lack of selfconfidence between the members, which were consistent with Fredrickson's differential emotional scale (2013), and Horwitz et al.'s (1986) scale of anxiety. Positive emotions such as enjoyment can facilitate learning and provide learners with opportunities to new experiences (Dewaele \& MacIntyre, 2014). These new experiences might be exercised within imagined communities which, as MacIntyre 
and Gregersen (2012) argued, might be rooted in the positive-broadening power of imagination.

Dewaele and MacIntyre (2014) further explained that enjoyment has two properties: a) development of interpersonal relationships and b) making progress towards a goal. Accordingly, Dewaele et al. (2016) observed both of these properties among the participants of their study as described in their own words. Based on their qualitative findings retrieved from an open-ended question, features such as pride, joy, interest, and excitement were mentioned by these participants. Generally, not only can positive emotions create an enjoyable environment for learning but also strong negative emotions can facilitate learning (Dewaele et al., 2016) despite their negative label. Dewaele and MacIntyre (2014) elaborated on the importance of both positive and negative emotions in language learning and their findings showed that their participants' levels of FLE were significantly higher than FLCA. Despite these recent studies, there is still lack of efficient research documents in the area of positive emotions within contexts in which learners can imagine new identities; hence, we have investigated these emotions, enjoyment and anxiety in particular, in the setting of imagined communities (Norton, 2001) in order to see how creating images of oneself in association with certain groups, whom they affiliate themselves with, can bring about positive and negative emotions.

\subsection{Imagined communities}

The term "imagined community was first coined by Benedict Anderson in 1991 indicating that what we think of as nations are in fact imagined communities "because the members of even the smallest nation will never know most of their fellow-members, meet them, or even hear of them, yet in the minds of each lives the image of their communion" (p. 6). People need to view themselves as members of a specific society that extends beyond their practices (Wenger, 1998). Wenger (1998) contended that imagined communities can be quite large and intangible like national communities. They can also represent dreams and goals one might come across in his or her life (Kanno, 2000, 2003). It seems that coming across these dreams might be emotion inducing.

Kanno and Norton (2003) defined imagined communities as members of inaccessible communities with whom we imagine to communicate. Norton (2001) was the first to apply imagined communities in an SLA context. Researchers have executed imagined communities in the areas of bilingualism (Kanno, 2000), linguistic understanding (Dagenais et al., 2009), racial discourse (Blackledge, 2003), identity (Schwieter, 2013), culture (Norton \& Kamal, 2003; Silberstein, 2003), and other areas of foreign language classrooms (see Anderson, 2006; Kanno \& Norton, 2003; Norton, 2001, 2010; Norton \& McKinney, 2011; Norton \& Toohey, 2011; Pavlenko \& Norton, 2007; Shoaib \& Dörnyei, 2005). Wenger (1998) introduced three modes of belonging to be a member of an imagined community of practice: first, imagination, which is the extent we create images of the world; second, engagement 
as the active involvement in order to pursue the imagination we have, and third, alignment known for coordinating our activities to fit within broader structures. Imagining oneself in an imagined community gives learners an opportunity to experience a new identity of what they desire to become in their imagination; thus, benefiting from this opportunity in their learning (Schwieter, 2013). Being provided with this opportunity to think about the person whom they desire to become might provide them with experiencing a range of feelings. Furthermore, the atmosphere of an imagined community provides learners with different imaginary events or occasions in which learners are supposed to make the required adaptations and as asserted by Reeves (2015), these adaptations might provoke different emotional responses.

The image of reaching a goal and progress in achievement can be seen in the features of both imagined communities and emotions like enjoyment as discussed earlier. Reflecting on the definition of imagined communities by Kanno and Norton (2003), being a member of inaccessible communities via the construction of imagined identities, we assume that the context of imagined community is more emotion evoking than the real context of class where students are assigned roles to play or carry out specific tasks. Thus, it seems to worth exploring emergent patterns of enjoyment and anxiety within these communities. While imagined communities have been executed in different areas of applied linguistics and second language learning, no study has been conducted to see the different kinds of emotion, positive and negative, experienced by learners of a foreign language while they are involved in the assignments related to their imagined identities. In other words, exploring levels of enjoyment and anxiety considering learners' constructed images of themselves and the extent it can be enjoyment raising or anxiety provoking have not been investigated yet.

\subsection{Research question}

What are the emerging patterns of foreign language anxiety and foreign language enjoyment in an imagined community?

\section{Method}

\subsection{Participants}

The participants of this study were three groups of six junior university students majoring in the field of teaching English as a foreign language (TEFL), all of whom were in a high intermediate level of English proficiency and had adequate background knowledge of literature and literary criticism since they had had a course in literary criticism in their previous semester. Since accuracy and fluency in using English might be common sources of anxiety in any class, learners with high intermediate level English were selected for the sample participants of this study so that we could focus on the sources of their emotions particular to their experiences 
in the imagined community they were involved in, not any other sources of anxiety associated with their fluency and accuracy in using their second language. Two groups were female participants, and one group included all male participants within the age range of 18 to 22 . The participants were selected based on the course they had just passed in literary criticism so that they could be familiar with the concepts.

\subsection{Procedure}

The members took part in a discussion panel in an imaginary TV program where they were to summarize a fiction they were assigned to read beforehand and discuss the fiction in one session known as the discussion day. Based on his or her imagined identity, every member of the group was assigned a role by the teacher as the host of the program. The basic principle was that the group members themselves selected the person they desired to become like the journalist, the photographer as well as the critic and developed their imagined identities based on them. We asked the members to keep a personal journal of their experiences and moments of enjoyment and anxiety throughout the entire process and write down whatever they experienced concerning their emotions, engagement, and thoughts with regard to the specific people they had affiliated themselves with. We observed the students from October to December 2016, focusing on their positive and negative emotionality in the context of the imagined community. The members defined their roles based on their imagined identities during the entire process. The teacher strengthened the setting of the imagined community by acting as the host of an imaginary television program and giving the necessary information to the group members so that they could construct their imagined identities.

The group members constructed four major imagined identities: a) the critics who gathered information while including their own critique, b) the reporters who were in charge of summarizing the information, taking notes, and paying attention to details to execute the final report for publication in a literary bulletin, c) the photographers who took pictures during working hours and provided pictures for the discussion day and for the final report, and d) the presenters who, while being the critics as well, presented the final summary on the discussion day in front of all the group members. Each of these imagined identities were consistent with the members' specific imagined assignments all leading to the final goal of each group in the imagined community as being selected by the host of the program and the imaginary viewers as the best group in presenting the critique of the story for each session. The teacher as the host of the TV program created an environment for the members to feel committed to their assignments. The stages of the developed imagined community contained five phases which are illustrated in Figure 1. The first phase was covered in one single session where each individual constructed an imagined identity; that is, he or she created an image of the person whom he or she desired to be. After the roles for each imagined identity were shared with the teacher as the host of the program, they were given one week to read the fiction and 
prepare themselves for phase 2. Phase 2 took 10 sessions, once every week, where they discussed the fiction, took notes, summarized, took photos, and organized their information to provide the best presentation on the discussion day, which was the third phase of this study. After ten sessions of discussions and photography, one session was entirely devoted to presentations (phase three) and questions and answers (phase four). After the presenters delivered their speech, other groups were given the opportunity to criticize the presentation and discuss different ideas and perspectives. By the end of the discussion day, reporters of the groups were asked to provide a final report from the beginning of the procedure to the end of the discussion day. The best report was chosen to be published in an imaginary literary bulletin.

\subsection{Data collection}

Since an interview is a "gold standard of qualitative research" (Silverman, 2000, p. 51 ), after each phase, we conducted an open-ended interview with the members and recorded it for further review and analysis. Following Creswell's suggestion (2013) that qualitative researchers gather information from multiple sources rather than a single source (Creswell, 2013); besides interviews and observation which were the base of our data collection in this study, narrative frames were applied to collect data unique to every individual. Narratives are stories and personal experiences (Connelly \& Clandinin, 1990; Pavlenko, 2007) which seemed suitable for our research since the learners wrote down their personal experiences regarding their imagined identities in the journals. 


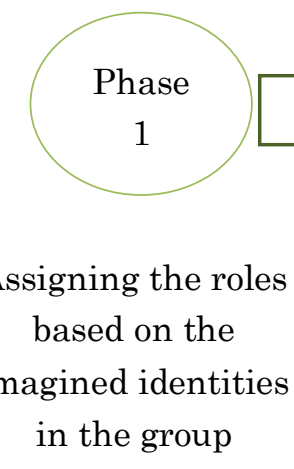

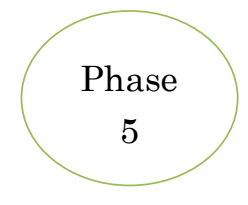

Final report

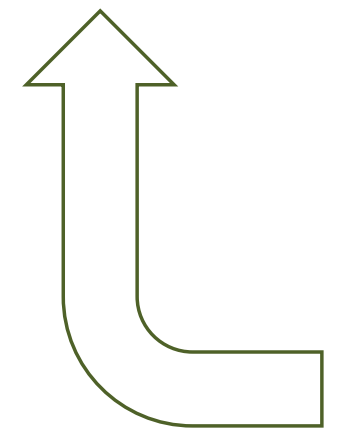
providing the notes for the presenter

Phase 2

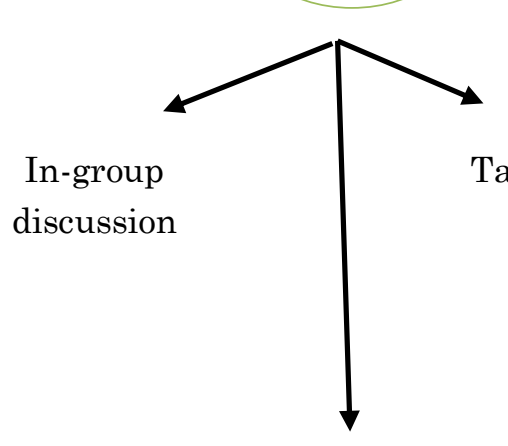

Taking pictures
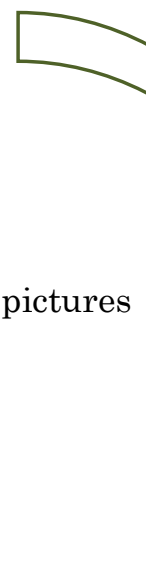

\section{Phase}

3

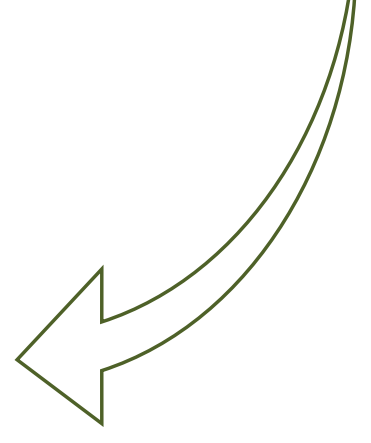

Presenting in front of the groups

Discussion, question \& answer

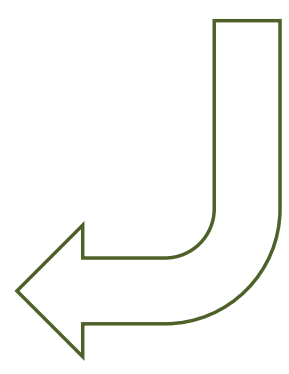

Figure 1: The participants' imagined community in the literary criticism discussion panel project 


\subsection{Data analysis}

We took advantage of grounded theory (Strauss \& Corbin, 1998) as a suitable method for data analysis since it provides researchers with "relevant predictions, explanations, interpretations, and applications" (Glaser \& Strauss, 1967 p. 1). Applying a qualitative content analysis, the data collected from the interviews were transcribed through MAXQDA software (Belous, 2012), and the narrative frames from the personal journals were read and reread carefully by both researchers in order to explore any sign of enjoyment, anxiety as well as validating the structure of the developed imagined community. Through reading the transcriptions and the journals, we found that some words and themes are used more often by the participants. Themes in analyzing qualitative data help develop ideas about different activities, behaviors, and definitions of oneself in certain situations or events one faces (Glaser \& Strauss, 1967; Mellon, 2015). The analysis included open coding, axial coding, and selective coding to explore both positive and negative emotions each member went through while doing his or her assignments in the imagined community. Open coding was proceeded through line by line in-depth examination of occurring events (Mellon, 2015). Open coding was done by both researchers in which we highlighted any word related to positive and negative emotions. This phase was repeated twice to make sure that we did not miss any signs of emotions. In order to check the reliability and validity of the coding system, each researcher coded the emerging themes separately; then, both checked them twice, and finally discussed any points of disagreement with each other to reach a consensus on them. The inter-coder reliability estimate turned out to be .89 . Among the highlighted words, we checked them all in order to find the most frequent ones used by the participants. Themes such as excitement, commitment, joy, fun, pride, fear, anxiety, low self-confidence, and self-doubt were the most observed ones in the open coding phase. In the axial coding phase of analyzing the data, consistent with many studies related to emotions, we came up with two categories: positive and negative emotions. We related emotions such as pride, love, interest, fun, enjoyment, to name a few, to positive emotions and fear, anxiety, to name a few, to negative emotions. In the final phase, selective coding, we selected two of the most frequently used traces of emotions, enjoyment and anxiety among the two categories of positive and negative emotions, which are also the most studied emotions in the field and outside the field of applied linguistics. The two themes were interpreted based on Glaser and Strauss's grounded theory; that is, studying actions and aspirations of people and explaining them through models which "fit empirical situations" (Denzin \& Lincoln, 2000, p. 14).

\section{Results}

The first section required to be presented is whether the participants actually created an imagined community. Accordingly, what Wenger (1998) described as the three modes of belonging and traces of enjoyment were observed in the process. 


\subsection{Imagination}

The participants described that they were deeply involved in imagining how the discussion day would go. Some evidence is as follows:

The second I decided to be the presenter, I just started imagining myself on the stage talking while everyone was looking at me. I kept reviewing in my mind how I would start my discussion, and what I would say. I aimed to show everyone what I was capable of, so I prepared myself for it and imagined every possible way the discussion day might go.

(Presenter of group 1, personal journal, October 2016)

Every time I took a photo of my group they would pose as a real critic. They were so much focused and involved in the exchange of information that many times they didn't even notice I was taking their photos. Those times I felt like I was a professional photographer knowing exactly when and where to click the camera.

(Photographer of group 3, personal journal, October 2016)

The group's feedback was so helpful that I tried out different application programs to make the photos look more artistic for everyone to enjoy. At times I would even hold the camera in a way that made me feel I had been doing this for years, and the camera was a part of me.

(Photographer of group 2, personal journal, December 2016)

\subsection{Engagement and active involvement}

Besides, there were elements of engagement and active involvement observed in the community of the imagined identities. Below you can see some examples indicating the level of engagement in the imagined community:

The love for literature is so deep in me. Being given this opportunity to express my own ideas in a setting like this was so amazing. I had never experienced the excitement of imagining myself as a critic before. I gathered information from every possible source and tried to present unique ideas. Since I was already familiar with criticism, I knew exactly what I had to do and which parts to focus on. I really enjoyed every second of my new identity. More important than that, could imagine myself among famous critics appearing on TV on the weekends.

(Critic of group 1, interview, December 2016)

While we were all discussing the fiction after the presentation and started arguing and criticizing, I couldn't help see all our effort fade when others began questioning some of our critiques. So I very quicklysearched the net to provide backup and proof for our arguments. This really made my images of a literacy critic alive and active. 
(Critic of group 2, open-ended questionnaire, December 2016)

Since I have imagined myself as the reporter of the group, and I have to prepare a final work of the group, I want to be the cherry on top so I have already started to make samples to show to my group and see what they think.

(Reporter of group 1, personal journal, October 2016)

\subsection{Alignment}

Preparation for the goals of each group and rehearsal in order to fit the broader structure was observed in the imagined community as well. You can see some evidence of alignment in the imagined community in the following examples.

My group members and I got together on Mondays and Tuesdays to share our information and update each other on the different aspects of the story critique. We practiced this for each story every week to be completely prepared for showing the full potential of our imagined identities on the final discussion and presentation day.

(Presenter of group 1, interview, December 2016)

We had conducted a virtual group including critics to strengthen the identities we had already imagined and to talk anytime we wanted because it was a bit difficult for all of us to get together sometimes. In the virtual group, everything was active as his or her imagined identity by sharing notes, ideas, and pictures. We would all argue and give ideas until we could reach a final conclusion.

(Critic of group 3, interview, December 2016)

Furthermore, cooperation and teamwork developed the interpersonal relationships among the imagined identities and the participants even affiliated themselves with real critics, reporters, and photographers within a broader community.

Table 1 indicates the types of emotions the participants of the study went through concerning their assigned roles in association with their imagined identities. As seen in the table, the participants mainly experienced positive emotions than negative emotions such as anxiety, with enjoyment as the main building block of these positive emotions. 
Table 1. Emotions experienced by different team members

Role

The responsibility of representing the whole group

Fear of mispronunciation

Forgetting the details

Time limit

Loving group mates support

Loving Collaboration

Positive feedback

Engagement as actors, not learners

Photographers

Reporters

Competitiveness

Excitement
Competitiveness

Having fun with the new way of learning

Enjoying group work

Pride

The host's positive feedback

Acting as professional photographers

The sense of satisfaction and enjoyment of their work

Pride

\subsection{Negative emotions}

Among the participants, the presenters experienced negative emotions, mainly anxiety, as explained in the interviews, due to the huge responsibility they imagined on their shoulders as their teams' final voice. However, this type of anxiety was not a debilitative one but a facilitative one since it contributed to the development of a cooperative air between the presenters and their group members working with more effort:

When we started dividing the tasks and deciding on selecting the roles related to our imagined identities, all of my group mates chose 
me as the presenter because of my high level of self-confidence. This made me so anxious because I knew I had to represent the whole group and present on behalf of them. Imagining this duty made me anxious but motivated me at the same time. I also knew that they were all going to work very hard to show the best of their imagined identities and to gain our common vision, so I didn't want to let them down and tried doing the best I could.

(Presenter of group 1, open-ended questionnaire, December 2016)

Time limitation was expressed negatively by the group members claiming they could have executed a better performance of their imagined roles and duties if they were not anxious about the time running out:

There was so much information and so many things to talk about as we tried to imagine well, but there was no time to mention everything written in the summaries as we had imagined, so I had to wrap it up and just point out the important parts. I felt bad afterwards because I thought I wasn't able to show how hard my group had imagined their assignments and worked on their summaries. If there were more time, I am sure I could have done a much better job.

(Presenter of group 3, open-ended Questionnaire, December 2016)

\subsection{Facilitative anxiety}

The most anxiety inducing moments of the participants' involvement in their imagined affiliations in this program, according to the photographers, were related to the responses everybody gave to the displayed pictures:

At first I couldn't imagine what type of pictures would be useful, and I saw the other photographer from the other group taking pictures from different angles. It seemed that he had imagined his identity so well and now had made it so tangible because his team members were really enjoying that. I got a little anxious but that somehow encouraged me to be more serious to imagine the things I can do as a photographer for my group. I wasn't quite sure how the teacher or the class would react to them but I really felt excited when he, as the host of the program, admired me for my artistic photos and took me serious. I felt proud with the feedback I got from him and my friends after the photos were displayed.

(Photographer of group 1, interview, December 2016)

Moreover, we observed how positive feedback from group mates and the teacher helped members overcome their low self-confidence and turn it around to enjoying their imagined assignments. 
I was in doubt to imagine myself as the presenter, but they all insisted on me being the presenter, so I felt a bit nervous imagining myself on the discussion day. I saw one of the presenters rehearsing in front of her group during the break time. This made me rather anxious but also triggered me to take my imagined role more serious than before.

(Presenter of group 3, personal journal, November 2016)

I was in charge of writing the final report of our group critique, which I imagined well, so I liked it very much but I felt my writing was not very good, and I tried to convince my friends to pick someone else. I saw how hard the group was working, and I didn't want to be a complete disappointment when finalizing the report. My friends encouraged me to believe in myself and this really made the image alive, which helped a lot because if they weren't so optimistic, I wouldn't have been able to do the job and enjoy it at the same time.

(Reporter of group 2, interview, December 2016)

\subsection{Enjoyment}

It is interesting that the photographers did not experience any amount of disruptive anxiety throughout the entire process; in fact, they actually loved imagining themselves as a professional artist. See the following examples.

On discussion day, I took a few pictures of the host of the program while he wasn't paying attention to. When it was our team's turn, the first picture I chose to be displayed was that. The whole participants laughed and the host started laughing as well which made me feel really happy. It was a really good start for our group and I think everyone enjoyed it including our teacher and myself because the teacher's acts as the host with his special influencing voice, facial expressions, and short reports of the performance seemed so telling in the pictures making our imagined identities stronger than before. .

(Photographer of group 3, open-ended questionnaire, December 2106)

Love, interest, contentment, and pride have been recognized as positive emotions (Fredrickson, 2003). Accordingly, what we observed of some features of emotions in this study can be categorized under the heading of enjoyment. The photographers, experiencing no amount of disruptive anxiety, went through a high level of enjoyment by doing their imagined role, setting the stage for the opportunities of creativity, fun, contentment, and competition with the other photographers as well as other famous real photographers: 
I was so much willing to be a photographer. I really enjoyed taking photos in the program because it gave me a great chance to show my artistic talent and to do what I like in a literary program.

(Photographer of group 2, open-ended questionnaire, December 2016)

In this study, cooperation between the reporters and the critics led to a feeling of joy and learning while competing with the other groups. The reporters and critics elaborated on their images being activated via the joyful period of group work, sharing ideas, organizing their notes in the collected interviews showing that teamwork held the pivot of the construction, and development of their imagined identities throughout the process. Some members elaborated on this fact:

Our group would come together twice a week to make our images alive by sharing whatever we had done and to plan everything. I loved how the critics were so serious and highlighted the important parts in their summaries.

(Reporter of group 1, personal journal, November 2016)

The best part of the project was that I really had fun working with the team, and all that group work led to developing my imagined identity further by learning a lot about literary critique and a lot of new related vocabulary and terminology.

(Reporter of group 3, interview, December 2016)

When you do something as a group member for improving the group performance, you feel the existence of the identities you have imagined, it is really enjoyable.

(Critic of group 1, personal journal, October 2016)

Furthermore, one of the participants developing the identity of a reporter in this study said:

When everybody is serious about their imagined identities, you would take that serious too especially when you are doing group work. From the beginning of the program, I noted down anything I thought which could be useful for the final report. It was meant to be published for everyone to see so I would write many drafts and edit them over and over again to get to the polished piece of work I really wanted, guaranteeing the possibility of being a reporter in the future.

(Reporter of group 3, interview, December 2016)

In one of the interviews, one of the participants constructing the imagined identities of a presenter and a critic at the same time expressed her joy of reaching her goal and accomplishment: 
I imagined the key to a good presentation was dominance, confidence, and rehearsal. I practiced while I was alone at home and in front of my friends many times. Sometimes I video recorded myself while rehearsing so I could self-assess and become aware of my mistakes. This helped me so much to turn my imagined identity into a more plausible one. My goal was to offer the best presentation possible and I think the presentation went even better than I imagined first.

(Presenter of group 1, interview, December 2016)

Our main desire was to have the best critiques to talk about when our presenter was doing her job as she had imagined well, I felt how strong our ideas and critiques were. They were exactly what we desired and wanted others to feel too.

(Critic of group 1, interview, December 2016)

Among the features of enjoyment described by Fredrickson (2003) and Kolehmainen (2017), we also could see love, pride, accomplishment, and interest amongst some members as they described this feeling and the joy it brought Some of the excerpt are as follows:

At first, the imagined assignments associated with each imagined identity seemed to be like a difficult job to do, but after a few gatherings with the group, I felt that I was becoming more and more interested in fiction and literature. Everyone in the group seemed so serious and while sharing their information, it made me push myself into doing my part as I had imagined primarily. During the process, my love for literature expanded and made the whole process of doing the roles of my imagined identity so enjoyable and fun for me.

\section{(Critic of group 2, interview, December 2016)}

One of the presenters explained how he imagined himself as a critic as well standing on stage and showing what he was capable of. He included the sense of enjoyment he experienced in receiving attention from others:

The most enjoyable part for me was where the idea of one of our classmates countered my statement, and I had to defend myself with all I had got imagining myself as the best critic ever.

(Presenter of group 2, open-ended questionnaire, December 2016)

Furthermore, the findings indicated the development of a strong sense of autonomy taking place in the imagined community. One of the participants activating the identity of a presenter reported:

I liked to break the rules of the normal classes and loved the experience of such creative activities resulted from the practice of our imagined identities. At first, I thought we were going to be evaluated with scores and it seemed like a difficult project, but when I saw our teacher 
playing the host of the program and setting the stage for us to practice our imagined identities, the atmosphere of the classroom totally changed from a teacher-learner environment to a fun and exciting TV show with all of us being active members and having a new identity in it.

(Presenter of group 3, personal journal, November 2016)

\subsection{Pride}

One presenter explained how receiving positive feedback from her friends encouraged her to do the best she could and filled her with a sense of pride, consistent with Fredrickson's (2003) description of enjoyment:

My group members didn't even ask my opinion about the person I desired to become, and just told me I should be the presenter. It made me full of pride because I saw how much they trusted me and count on me, and I loved the way they commented on my presentations, which made my desire to become a presenter a firm choice. I did have a lot of self-esteem when it came to presenting, but the fact that my friends made positive comments on it was exactly what made me so excited to take pride in the identity I had developed.

(Presenter of group 1, personal journal, October 2016)

I should do my best to get the best results, also I think my partners are the best, they do great as a group member so they deserve to be number one in everything.

(Reporter of group 3, interview, December 2016)

I enjoyed the discussion after the presentations a lot. I had studied so much about the fiction that when one of the other group members pointed out something, I knew exactly which website he had checked and we started arguing about the validity of the report on that website. That sense of competition was amazing, and I felt really proud of myself.

(Critic of group 1, interview, December 2016)

What we observed as enjoyment is very much similar to Dewaele et al.'s (2016) findings on gender differences in experiencing emotions. Putting aside gender differences as the main purpose of their study, their description of enjoyment is almost consistent with the one in the current study. Dewaele et al. (2016) described how learning with peers in enjoyable and fun ways strengthens interpersonal relationships and the goal of being able to use an FL causes excitement which are the two main features of enjoyment and which were both observed in this study. Moreover, the participants in their study elaborated on the sense of pride they gained, which was also observed in the group members of this study when they had 
achieved their goal. Besides these factors, enjoyment in a novel and interesting environment led to more creativity and motivation in both studies.

The task used in this study seemed to play a significant role in enhancing enjoyment. However, other tasks such as dealing with outside of the class members can cause different emotional experiences as well as more serious imagined communities. In a place where the imagined community is closer to reality, one might put more effort in the tasks.

\section{Discussion}

In line with Norton and Toohey (2011), the findings of this study showed that learners acted in a desired community enabling them to construct imagined affiliations with certain groups of people like photograpers, journalists, critics, and reporters. In addition, consistent with Schwieter (2013), the results of the study showed that what the learners experienced in the community provided them with sufficient thinking phase regarding the person they desired to become. To put in another way, in accordance with Wenger (1998), transcending time and space, they viewed themselves in new identities of a critic or a photographer and consistent with Anderson (1991) and Kanno and Norton (2003), each learner shaped the image of communication with those who are not accessible now like real photographers, real journalists, and real critics.

The results of this study showed that the setting of an imagined community can set the stage for the emergence of positive and negative emotions with both types of emotions facilitating the process of learning. Similar to Kolehmainen (2017) on studying positivity as a resource for learning, positive orientations such as interest, accomplishment, pride, membership in a group, creativity, tolerating imperfections were also observed in this setting.

Being provided with this opportunity to think about the person whom they desire to become, the participants in this study went through an array of feelings including anxiety and enjoyment. This might be rooted in the fact that the atmosphere of an imagined community provided them with different imaginary events or occasions in which the participants needed to make adaptations and, as asserted by Reeves (2015), these adaptations were accompanied with emotional responses.

As the findings of this study indicated, the participants involved in the imagined community experienced enjoyment more than anxiety, which is in line with Dewaele \& MacIntyre (2014) as well as Dewaele et al. (2017) who found that enjoyment and anxiety are two separate and independent phenomena in which the existence of one would not affect the existence of the other. That is, the states of anxiety experienced by learners within this imagined community, consistent with Arnold and Brown (1999), Dewaele and MacIntyre (2014), and MacIntye and Vincze (2017), pushed the learners forward to take actions in the process of learning and no cases of disruptive anxiety, as observed in previous studies (e.g. Eysenck, 1979; Gregersen \& Horwitz, 
2002; MacIntyre \& Gardner, 1994a, 1994b) overshadowing the participants' learning as well as their interpersonal relations.

In other words, moments of going through anxiety due to the construction of imagined identities, as felt at a high level by the three participants with the imagined identity of a presenter, not only did not weaken the participants' selfimages, in contrast with (Cohen \& Norst, 1989), but also, in accordance with (MacIntyre \& Vincze, 2017), motivated them to strengthen their images.

On the other hand, the sense of enjoyment experienced by the participants, shaped within the imagined community could boost the goal-oriented images of the participants. This is supported by Dewaele et al. (2016) observing that lack of selfconfidence in some activities was overcome by some other enjoyable activities. Furthermore, the positive drive of enjoyment emerging in the imagined community influencing the performance of the participants was supported by Gardner (1985, 2010) as well as Dewaele and MacIntyre (2014) contending that positive emotions such as interest and enjoyment have a significant role in the process of learning. In addition, similar to Brittany in the study of Dewaele et al. (2016) who took pride in her essay writing, the participants identifying themselves as a reporter took pride in their final reports, indicating the moments of utmost joy and pleasure.

In fact, the findings indicated that being involved in the imagined community; firstly, the learners developed imaginary interpersonal associations with the groups or people they were affiliated with and; secondly, made effort to reach their desired imagined identity which refer to the main two properties of enjoyment reported by Dewaele and MacIntyre (2014). Developing a social bond, as observed in this study, was also found as a significant source of enjoyment in a study conducted by Kolehmainen (2017). In other words, the high level enjoyment experienced by learners in the imagined community can be regarded as significant investment towards reaching the group's goals which; as a consequence, increases commitment an individual makes for the sake of the group and approaching the goals (Dörnyei \& Murphy, 2003) which are in line with Deweale and MacIntyre's (2014) second property of enjoyment, the progress of reaching a goal. Thus, the goal-oriented setting of the imagined community in terms of showing the potential of the imagined identities, consistent with Arnold (2011), defined achievement for the participants as the route to enjoyment. This is also in accordance with Kolehmainen (2017) concluding that the feeling of accomplishment increases enjoyment to a high extent.

The role of the teacher in the consolidation of the imagined community and the emergence of enjoyable moments for the participants acting according to their imagined identities should not be neglected. Teachers need to provide an environment in which the students feel emotionally safe and encouraged to experiment (see Arnold, 1999; Baider, Cislaru, \& Coffey, 2015; Borg, 2006; Dewaele, 2015; Dörnyei \& Csizer, 1998; Dörnyei \& Murphy, 2003; Gregersen \& MacIntyre, 2014). One of these experiments can be related to the opportunities given to the students to think about or imagine the desirable person they like to become. Playing 
the host of the program, the learners' images of the person they desired to be in the program were strengthened and turned plausible. This is in agreement with Pemberton and Cooker (2012), arguing that learners have more fun and use enjoyable ways of learning under the control and influence of a teacher.

\section{Conclusions}

It is important to strike a balance between the positive and negative emotions since they both influence learning and using a foreign language. Positive emotions during the process of using English as a foreign language in an imagined community resulted in a large impact on the emergence of positive emotions and commitment to the group members. Although anxiety was observed to some extent, it did not have a debilitative effect on the outcome; as a matter of fact, it held a positive reinforcement on the members, increasing their effort to pursue the goals of their imagined affiliations as well as boosting their sense of competition. What the members experienced as group work in their imagined community was the most enjoyable part of the program for them. In alignment with Fredrickson (2007) as well as Deweale and Alfawzan (2018), we saw in the current study that enjoying the process and the nature of the assigned roles in the imagined community, not only led to fun and excitement in achieving the goals set by the imagined identities but also carried out a novel way to experience learning with greater ease. Regarding the pedagogical implications of the findings of this study, we can refer to the practice and development of imagined communities by the teachers in the ecology of the classroom so that learners of English language can experience higher levels of enjoyment as well as lower levels of anxiety at the same time. Further studies can be conducted to explore the other variables of positive and negative psychology in the environment of the imagined community. In addition, both FLE and FLA can be investigated in other types of imagined community.

\section{References}

Anderson, B. (1991). Imagined communities: Reflections on the origin and spread of nationalism. London: Verso.

Anderson, B. (2006). Imagined communities: Reflections on the origin and spread of nationalism. London: Verso Books.

Arnold, J. (2011). Attention to affect in language learning. Anglistik. International Journal of English Studies, 22(1), 11-22.

Arnold, J. \& Brown, H. (1999). A map of the terrain. In J. Arnold (Ed.), Affect in language learning (pp. 1-24). Cambridge: Cambridge University Press.

Baider, F., Cislaru, G., \& Coffey, S. (2015). Apprentissage, enseigement et affects (Learning, teaching and affects). Le language et l'homme, 50(1), 3-6.

Belous, I. (2012). MaxQDA 11 [Computer software]. Marburg, Germany: Verbi Software. Retrieved from http://www.maxqda.com/

Blackledge, A. (2003). Imagining a monocultural community: Racialization of cultural practice in educational discourse. Journal of Language, Identity and Education, 2(4), 331347. 
Borg, S. (2006). The distinctive characteristics of foreign language teachers. Language Teaching Research, 10(1), 3-31.

Boudreau, C., MacIntyre, P. D., \& Dewaele, J. M. (2018) Enjoyment and anxiety in second language communication: An idiodynamic approach. Studies in Second Language Learning and Teaching, 8(1), 149-170.

Bown, J., \& White, C. J. (2010). Affect in a self-regulatory framework for language learning. System, 38(3), 432-443.

Cheng, Y. (2002) Factors associated with foreign language writing anxiety. Foreign Language Annals, 35(6), 647-656.

Cheng, Y., Horwitz, E., \& Schallert, D. (1999) Language anxiety: Differentiating writing and speaking components. Language Learning, 49(3), 417-446.

Cohen, Y., \& Norst, M. J. (1989). Fear, dependence and loss of self-esteem: Affective barriers in second language learning among adults. RELC Journal, 20(2), 61-77.

Connelly, M., Clandinin, D., (1990). Stories of experience and narrative inquiry. Educational Researcher, 19(2), 2-14.

Creswell, J. W. (2013). Research design: Qualitative, quantitative, and mixed methods approaches. London: Sage publications.

Dagenais, D., Moore, D., Lamarre, S., Sabatier, C. \& Armand, F. (2009). Linguistic landscape and language awareness. In E. Shohamy \& D. Gorter (Eds), Linguistic Landscape: Expanding the Scenery (pp. 253-69). New York: Routledge.

Denzin. K. \& Lincoln. Y. S. (2000) Handbook of Qualitative Research. Sage publications, Thousand Oaks, California.

Dewaele, J.-M. (2015). On emotions in foreign language learning and use. The Language Teacher, 39(3), 13-15.

Deweale, J-M. \& Alfawzan, M. (2018). Does the effect of enjoyment outweigh that of anxietyin foreign language performance? Studies in Second Language Learning and Teaching, 8(1), 21-45.

Dewaele, J.-M., \& Dewaele, L. (2017). The dynamic interactions in foreign language classroom anxiety and foreign language enjoyment of pupils aged 12 to 18. A pseudolongitudinal investigation. Journal of the European Second Language Association, 1(1). 120.

Dewaele, J.-M., \& Ip, T. S. (2013). The link between Foreign Language Classroom Anxiety, Second Language Tolerance of Ambiguity and self-rated English proficiency among Chinese learners. Studies in Second Language Learning and Teaching 3(1), 47-66.

Dewaele,J.-M., \& MacIntyre, P. D. (2014). The two faces of Janus? Anxiety and Enjoyment in the Foreign Language Classroom. Studies in Second Language Learning and Teaching, 4(2), 237-274.

Dewaele,J.-M., \& MacIntyre, P. D. (2016). Foreign Language Enjoyment and Foreign Language Classroom Anxiety. The right and left feet of FL learning? In P. D. MacIntyre, T. Gregersen, \& S. Mercer (Eds.), Positive Psychology in SLA (pp. 215-236). Bristol: Multilingual Matters.

Dewaele, J.-M., \& Pavlenko, A. (2001). Web questionnaire bilingualism and emotions. London: London University Press.

Dewaele, J-M., MacIntyre, P. D., Boudreau, C., \& Dewaele, L. (2016). Do girls have all the fun? Anxiety and enjoyment in the foreign language classroom. Theory and practice of second language acquisition, 2 (1), 41-63.

Dewaele, J. M., Witney, J., Saito, K., \& Dewaele, L. (2017). Foreign language enjoyment and anxiety: The effect of teacher and learner variables. Language Teaching Research, 1-22. doi.org/10.1177/1362168817692161 
Dörnyei, Z. (2005). The psychology of the language learner: Individual differences in second language acquisition. Mahwah, NJ: Lawrence Erlbaum.

Dörnyei, Z., \& Murphey, T. (2003). Group dynamics in the language classroom. Cambridge: Cambridge University Press.

Dörnyei, Z., \& Csizér, K. (1998). Ten commandments for motivating language learners: Results of an empirical study. Language teaching research, 2(3), 203-229.

Elahi Shirvan, M., \& Taherian, T. (2018). Longitudinal examination of university students'foreign language enjoyment and foreign language classroom anxiety in the course of general English: latent growth curve modeling. International Journal of Bilingual Education and Bilingualism. doi.10.1080/13670050.2018.1441804

Elahi Shirvan, M., \& Talebzadeh, N. (2017). English as a foreign language learners' anxiety and interlocutors' status and familiarity: An idiodynamic perspective. Polish Psychological Bulletin, 48(4), 489-503.

Elahi Shirvan, M., \& Talebzadeh, N. (2018a). Exploring the Fluctuations of Foreign Language Enjoyment in Conversation: An Idiodynamic Perspective. Journal of Intercultural Communication Research, 48(1), 1-17.

Elahi Shirvan, M., \& Talezadeh, N. (2018b). Is Transparency an Illusion? An Idiodynamic Assessment of Teacher and Peers' Reading of Nonverbal Communication Cues of Foreign Language Enjoyment. Journal of Intercultural Communication Research, doi.org/10.1080/17475759.2018.1453527

Elkhafaifi, H. (2005). Listening comprehension and anxiety in the Arabic language classroom. Modern Language Journal, 89(2), 206-220.

Eysenck, M. W. (1979). Anxiety, learning and memory: A reconceptualization. Journal of Research in Personality, 13(4), 363-385.

Fredrickson, B. L. (2003). The value of positive emotions. American Scientist, 91(4), 330-335.

Fredrickson, B. L. (2013). Positive emotions broaden and build. Advances in Experimental Social Psychology, 47(1), 1-53.

Gardner, R. C. (1985) Social psychology and second language learning: The role of attitudes and motivation. London: Edward Arnold.

Gardner, R. C. (2010) Motivation and second language acquisition: The Socioeducational Model. New York: Peter Lang

Garrett, P., \& Young, R. (2009). Theorizing affect in foreign language learning: An analysis of one learner's responses to a communicative-based Portuguese course. The Modern Language Journal, 93(2), 209-226.

Glaser, B., \& Strauss, A. (1967). The discovery of grounded theory. Chicago: Aldine

Gregersen, T., \& Horwitz, E. (2002) Language learning and perfectionism: Anxious and nonanxious language learners' reactions to their own oral performance. Modern Language Journal, 86(4), 562-570.

Gregersen, T., MacIntyre, P. D. (2014). Capitalizing on individual differences: From premise to practice. Bristol: Multilingual Matters.

Gregersen, T., Macintyre, P. D., \& Meza, M. D. (2014). The motion of emotion: Idiodynamic case studies of learners' foreign language anxiety. The Modern Language Journal, 98(2), 574-588.

Hewitt, E., \& Stephenson, J. (2012). Foreign language anxiety and oral exam performance: A replication of Phillips's MLJ study. Modern Language Journal, 96, 170-189.

Horwitz, E. K. (1990). Attending to the affective domain in the foreign language classroom. In S. S. Magnam (Ed.), Shifting the instructional focus to the learner (pp. 15-33). Middlebury, VT: Northeast Conference on the Teaching of Foreign Languages. 
Horwitz, E. K. (2001). Language anxiety and achievement. Annual Review of Applied Linguistics, 21(1), 112-126.

Horwitz, E. K. (2010). Foreign and second language anxiety. Language Teaching, 43(2), 154167.

Horwitz, E. K., Horwitz, M. B., \& Cope, J. (1986). Foreign language classroom anxiety. The Modern Language Journal, 70, 125-132.

Imai, Y. (2010). Emotions in SLA: New insights from collaborative learning for an EFL classroom. Modern Language Journal, 94(2), 278-292.

Kanno, Y. (2000). Bilingualism and identity: The stories of Japanese returnees. International Journal of Bilingual Education and Bilingualism, 3(1), 1-18.

Kanno, Y. (2003). Negotiating bilingual and bicultural identities: Japanese returnees betwixt two worlds. Mahwah, NJ: Lawrence Erlbaum Associates, Inc.

Kanno, Y. \& Norton, B. (2003). Imagined communities and educational possibilities. Journal of Language, Identity, and Education, 2(4), 241-49.

Kleinmann, H. H. (1977). Avoidance behaviour in adult second language acquisition. Language Learning, 27(1), 93-107.

Kolehmainen, M. (2017). Positivity as a resource for learning: enjoyment in the English classroom in Finland (bachelor's thesis). University of Jyväskylä, Jyväskylä, Finland.

Lu, Z., \& Liu, M. (2011). Foreign language anxiety and strategy use: A study with Chinese undergraduate EFL learners. Journal of Language Teaching and Research, 2(6), 12981305.

MacIntyre, P. D. (1999). Language anxiety: A review of the research for language teachers. In D. J. Young (Ed.), Affect in foreign language and second language teaching: A practical guide to creating a low-anxiety classroom atmosphere (pp. 24-45). Boston: Mc Graw-Hill.

MacIntyre, P. D., \& Gardner, R. C. (1994a). The effects of induced anxiety on cognitive processing in computerised vocabulary learning. Studies in Second Language Acquisition, 16(1), 1-17.

MacIntyre, P. D., \& Gardner, R. C. (1994b). The subtle effects of language anxiety on cognitive processing in the second language. Language Learning, 44(2), 283-305.

MacIntyre, P. D., \& Gregersen, T. (2012). Emotions that facilitate language learning: The positive-broadening power of the imagination. Studies in Second Language Learning and Teaching, 2, 193-213.

MacIntyre, P. D., \& Legatto, J. J. (2010). A dynamic system approach to willingness to communicate: Developing an idiodynamic method to capture rapidly changing affect. Applied Linguistics, 32(2), 149-171.

MacIntyre, P., \& Vincze, L. (2017). Positive and negative emotions underlie motivation for L2 learning. Studies in Second Language Learning and Teaching, 7(1), 61-88.

Mellon, C. A. (2015). Library anxiety: A grounded theory and its development. College \& Research Libraries, 76(3), 276-282.

Murphy, R. S. (2010). Where does psychology and second language acquisition research connect? An interview with Zoltán Dörnyei. The Language Teacher, 34(2), 19-23.

Norton, B. (2000). Identity and Language Learning: Gender, Ethnicity and Educational Change. London: Pearson Education.

Norton, B. (2001). Non-participation, imagined communities, and the language classroom. In M. Breen (Ed.), Learner Contributions to Language Learning: New Directions in Research (pp. 159-71). London: Pearson Education

Norton, B. (2010). Language and identity. In N. Hornberger \& S. McKay (Eds), Sociolinguistics and Language Education (pp. 349-69). Bristol: Multilingual Matters. 
Norton, B., \& Kamal, F. (2003). The imagined communities of English language learners in a Pakistani school. Journal of language, identity, and education, 2(4), 301-317.

Norton, B. \& McKinney, C. (2011). An identity approach to second language acquisition. In D. Atkinson (Ed.), Alternative Approaches to Second Language Acquisition (pp. 73-94). Oxford: Routledge.

Norton, B., \& Toohey, K. (2011). Identity, language learning, and social change. Language teaching, 44(4), 412-446.

Pavlenko, A., (2007). Autobiographical narratives as data in applied linguistics. Applied Linguistics, 28 (2), 163-188.

Pavlenko, A. \& Norton, B. (2007). Imagined communities, identity, and English language learning. In J. Cummins \& C. Davison (Eds), International Handbook of English Language Teaching (pp. 669-80). New York: Springer.

Pemberton, R., \& Cooker, L. (2012). Self-directed learning: Concepts, practice, and a novel research methodology. In S. Mercer, S. Ryan, \& M. Williams (Eds). Psychology for language learning: Insights from research, theory and practice (pp. 203-219). London: Palgrave Macmillan.

Piniel, K. \& Albert, A. (2018). Advanced learners' foreign language-related emotions across the four skills. Studies in Second Language Learning and Teaching, 8(1), 127-147

Reeve, J. (2015). Understanding motivation and emotion (6th ed.) Hoboken, NJ: Wiley.

Rivers, W. (1981). Teaching foreign language skills. Chicago: The University of Chicago Press.

Saito, Y., Garza, T., \& Horwitz, E. (1999). Foreign language reading anxiety. The Modern Language Journal, 83(2), 202-218.

Scovel, T. (1978). The effect of affect on foreign language learning: A review of the anxiety research. Language Learning, 28(1), 129-142.

Shoaib, A. \& Dornyei, Z. (2005). Affective in life-long learning: Exploring L2 motivation as a dynamic process. In P. Benson and D. Nunan (Eds), Learners' Stories: Difference and Diversity in Language Learning (pp. 22-41). Cambridge: Cambridge University Press.

Schwieter, J. W. (2013). The foreign language imagined learning community: Developing identity and increasing investment. In D. J. Rivers and S. A. Houghton (Eds.). Social identities and multiple selves in foreign language education (pp. 139-155). A\&C Black.

Silberstein, S. (2003). Imagined communities and national fantasies in the O. J. Simpson case. Journal of Language, Identity, and Education, 2(4), 319-30.

Silverman, D. (2000). Doing qualitative research. London: Sage Publications.

Strauss, A., \& Corbin, J. (1998). Basics of qualitative research: Techniques and procedures for developing grounded theory ( $2^{\text {nd }} \mathrm{ed}$.). Thousand Oaks, CA: Sage.

Swain, M. (2013). The inseparability of cognition and emotion in second language learning. Language Teaching, 46(2), 195-207.

Wenger, E. (1998). Communities of Practice: Learning, Meaning, and Identity. Cambridge: Cambridge University Press.

Williams, M., Burden, R., Poulet, G., \& Maun, I. (2004). Learners' perceptions of their successes and failures in foreign language learning. Language Learning Journal, 30(1), $19-29$.

\section{Copyrights}

Copyright for this article is retained by the author(s), with first publication rights granted to the Journal.

This is an open-access article distributed under the terms and conditions of the Creative Commons Attribution license (CC BY-NC-ND) (http://creativecommons.org/licenses/by-nc-nd/4.0/). 